\title{
EMULSION PROBLEMS IN MARGARINE MANUFACTURE
}

\author{
BY \\ WILLIAM CLAYTON, M.So.
}

Margarine is a substitute for butter, certain animal and vegetable oils and fats replacing butterfat. The oils and fats are liquefied together in certain proportions depending on the quality of the margarine required, and then churned with soured milk to form an emulsion. This emulsion is rapidly cooled, either by means of a spray of ice-cold water under pressure, or by flowing on to well-cooled revolving drums. The product in each case is then worked up by suitable kneading machinery to the required butter consistency and texture.

Margarine manufacture offers a splendid field for colloid research in several directions, but particularly in emulsions, both liquid and solid. Practically no published work appears on solid emulsions like butter and margarine, and as regards liquid emulsions, practice in margarine manufacture has followed empirical rules rather than definite physico-chemical conclusions.

The present discussion may conveniently include three main points in the making of a margarine emulsion :-

(a) Factors depending on the degree and mode of agitation employed in mixing.

(b) Factors depending on the animal and vegetable oils and fats used.

(c) Factors depending on the water, milk, and other ingredients employed.

\section{(a) Factors depending on the Degree and Mode of Agitation EMPLOYED IN MIXING}

The most essential factor in the production of a margarine of a butter-like texture, is the preparation of a stable and suitably-phased emulsion ${ }^{1}$ containing from 77 per cent. to 84 per cent. fat and 23 per cent. to 16 per cent. water (milk serum). The milk used is at a temperature of about $7^{\circ} \mathrm{C}$., and the melted mixture of oils and fats at about $40^{\circ} \mathrm{C}$. Before actually chilling the emulsion its temperature is reduced to about $24^{\circ} \mathrm{C}$., so that a thick custard-like emulsion ensues, of greatly enhanced stability. This greater stability is due to the viscosity of the system, and furnishes an instance where viscosity is desirable in emulsion preparation. ${ }^{2}$ The object of chilling the emulsion is to fix the fine-grained condition arrived at, whereby the desirable intimate and finely-divided mixture is maintained in the solid state. Any " breaking " of the emulsion would lead to the formation of unemulsified fat, whereby the texture of the final product would be unsatisfactory.

Two types of emulsifying machines are in common use in margarine manufacture. The first is essentially a jacketed tank, permitting temperature control by circulating either hot or cold water. Milk is admitted to the tank, and then the oil mixture slowly run in, whilst constant agitation is maintained, e.g., by means of rapidly-revolving baffle plates. 
It is absolutely essential to run the oils into the milk, and not vice-versa. ${ }^{3}$ Thus a fine-grained emulsion results, of the oil-in-water type, which on cooling to $24^{\circ} \mathrm{C}$. (with constant agitation) becomes remarkably permanent. The more slowly the oil is run in, the better the results obtained.

If on the other hand the oils be in the churn in bulk and the milk run in, an emulsion of the water-in-oil type ensues. The same thing happens if both phases are placed in bulk in the churn (say 80 per cent. oil and 20 per cent. milk) without undue mixing, and then the agitating device set in motion. On consideration of volume factors alone, it will be evident that if one has the oil pnase in bulk and milk is introduced, stirring continually, the conditions from the purely mechanical aspect of disintegration of particles favour the formation of the water-in-oil type of emulsion. Such an emulsion is not "permanent." As soon as the agitation ceases, separation into layers occur, owing to the fact that the very nature of the emulsifying agents present, viz., milk colloids, demands the oppositely-phased system. Of course, this water-in-oil type emulsion can be "fixed" by any of the methods of rapid chilling used in margarine manufacture, but even then, the solid emulsion produced is far from satisfactory in the subsequent processes, and may well lead to a final margarine of poor texture.

The second type of emulsifying machine aims at the continuous production of emulsions, whereby there is economy in space, time, and power. The principle underlying continuous churns is the simultaneous admission of the oils and milk into a thermo-regulated chamber, whence, after some suitable device has ensured intimate mixing, an emulsion is discharged in a continuous stream. ${ }^{4}$ It is at once apparent that the same degree of freedom of the control of physical or mechanical factors is not permitted with this churn as with the older tank type. In my experience, even when using milk and oils, i.e., when the purely physico-chemical conditions are satisfied, different mechanical treatments may lead to either the oil-in-water or water-in-oil type of emulsion. Sometimes, the passage through a continuous churn (wherein blades revolving 1,500 r.p.m. cause violent agitation) of a margarine emulsion of the oil-in-water type, will completely reverse the type of emulsion. Probably volume factors exercise a marked influence in such inversions.

It may be noted here that the nature of a margarine solid emulsion can be determined by staining with Sudan and examining under the microscope, ${ }^{5}$ or by extending Briggs' ${ }^{6}$ drop-method of dilution, by placing a small piece of the margarine in cottonseed oil at $15^{\circ} \mathrm{C}$.; if the margarine is of the water-in-oil type, it slowly dissolves, if of the opposite type, it is unaffected. An electrical method was proposed by the author, ${ }^{7}$ based on the idea that though a small conductivity may result in an emulsion of the oil-in-water type, practically no conductivity would be observed in the case of a water-in-oil emulsion. That such a scheme is practicable has recently been shown by Sherrick ${ }^{8}$ and by Bhatnagar. ${ }^{9}$

The effects of different methods of agitation, and the degree of any one kind, on a mixture of oil and an aqueous phase, deserve far more attention than hitherto given. Undoubtedly one can both make and "break" an emulsion by agitation. Thus Sheppard,10 working on the emulsification of nitrobenzene in sulphuric acid, found that "de-emulsification was accelerated by slow shaking or even single vibration in some cases, for emulsions which remained stable 
at rest, while shaking gently at a slightly higher frequency would re-emulsify to a system again stable at rest." The influence of vibration on emulsions has been noted by Ayres, ${ }^{11}$ and he mentions an instance where an emulsion, so stable as to defy separation in a centrifuge, was de-emulsified by the vibration attendant upon its transport in an express railway train.

The prevalent idea regarding emulsification in general, and margarine churning in particular, is to agitate the mixture of milk and oils as violently as possible. Such agitation, it has been argued, results in the formation of very small globules, a most desirable feature in a stable emulsion. Consequently an empirical limit only is set on the degree of stirring up an emulsion. For any given type of emulsifying machine, it seems reasonable to believe that an optimum degree of agitation is possible, favouring a very stable system.

Shaking is an inferior method of making emulsions, because as the emulsion becomes more perfect, the smashing action between the relatively heavy and light particles becomes more feeble, whereas the smashing forces should be increased. Briggs ${ }^{12}$ has recently shown that "intermittent shaking was vastly more effective than uninterrupted agitation," and that "intermittent shaking may be six hundred or even a thousand times more effective than uninterrupted but equally violent agitation." From his results, it would appear that the ideal process of emulsification is one wherein the dispersed phase is as completely disintegrated as possible, whilst the continuous medium is left as far as possible unbroken. It seems to me that continuous shaking would give equally as good results as the intermittent shaking, provided the emulsified portions of the mixture are continually removed from the mass so that the energy of shaking is concentrated on the remainder.

\section{(b) Factors depending on the Animal and Vegetable Oils and FATS USED}

The solid fats used in margarine manufacture include stearine (M.Pt. $=50^{\circ} \mathrm{C}$. $)$, beef-jus $\left(48^{\circ} \mathrm{C}\right.$. $)$, oleo $\left(30^{\circ} \mathrm{C}.\right)$, lard $\left(33^{\circ} \mathrm{C}.\right)$, palmkernel oil $\left(28^{\circ}\right.$ C. $)$, and coconut oil $\left(25^{\circ}\right.$ C. $)$, whilst the liquid oils include cottonseed, arachis, soya, rape, sesame, etc. A margarine mixture may include from three to six of these ingredients, so proportioned as to give a melting-point of about $26^{\circ} \mathrm{C} .1^{13}$

Experiments have been made to inquire whether these various ingredients were alike in their capacity of being emulsified, or whether by a suitable choice of oils and fats, a margarine mixture could be obtained which would with greater ease give an emulsion of more than the usual stability. Using the Donnan drop-pipette, numerous drop number determinations were made of various oils and fats against water at various temperatures.

The first point observed was the fact that only a small difference in drop numbers exists for these oils and fats, e.g., at $35^{\circ} \mathrm{C}$. against pure water, the following numbers were repeatedly observed :-

\begin{tabular}{|c|c|c|}
\hline $\begin{array}{l}\text { Palm kernel oil } \\
\text { butterfat } \\
\text { cottonseed oil } \\
\text { coconut oil }\end{array}$ & $\begin{array}{l}=74 \\
=71 \\
=65 \\
=61\end{array}$ & $\begin{array}{l}\text { lard } \\
\text { oleo } \\
\text { arachis oil } \\
\text { soya bean oil }\end{array}$ \\
\hline
\end{tabular}

The effect of the free-fatty acids in edible oils is small. Thus no change in drop number was given by various samples of the liquid oils, with free fatty acid contents ranging from 0.05 per cent. (as 
oleic acid) to 0.5 per cent., the figures usually found. The coconut oils and palm-kernel oils investigated had free fatty acid contents of 0.05 per cent. to 0.08 per cent. (as lauric acid). A coconut oil not so well refined as the usual edible oil employed in margarine, and possessing a distinct odour of coconut, had 1.85 per cent. of free lauric acid, and the drop number at $35^{\circ} \mathrm{C}$. was 73 instead of the usual figure 61 .

Temperature has no pronounced influence on the interfacial tension, an observation agreeing with the results of Meunier and Maury, ${ }^{14}$ though they used oils very different to mine.

\section{Effect of Temperature on Drop Number}

\begin{tabular}{|c|c|c|c|}
\hline \multicolumn{2}{|c|}{$\begin{array}{l}\text { Arachis } \\
\text { Oil-water. }\end{array}$} & $\begin{array}{l}\text { Cottonseed } \\
\text { Oil-water. }\end{array}$ & $\begin{array}{l}\text { Coconut } \\
\text { Oil-water. }\end{array}$ \\
\hline $\begin{array}{l}25 \cdot 5^{\circ} \mathrm{C} .=6 \\
46 \cdot 0^{\circ} \mathrm{C} .=6 \\
50 \cdot 0^{\circ} \mathrm{C} .=6\end{array}$ & $\begin{array}{l}\text { ps. } \\
\text { ps. } \\
\text { drops. }\end{array}$ & $\begin{array}{l}27 \cdot 5^{\circ} \mathrm{C}=65 . \\
35 \cdot 0^{\circ} \mathrm{C}=65 . \\
50 \cdot 0^{\circ} \mathrm{C}=63 .\end{array}$ & $\begin{array}{r}30^{\circ} \mathrm{C}=69 \\
35 \cdot 0=61 \\
50 \cdot 0=65\end{array}$ \\
\hline $\begin{array}{l}\text { Palm Kernel } \\
\text { Oil-water. }\end{array}$ & $\begin{array}{c}\text { Soya Bean } \\
\text { Oil-water. }\end{array}$ & $\begin{array}{l}\text { Lard- } \\
\text { water. }\end{array}$ & $\begin{array}{l}\text { Oleo- } \\
\text { water. }\end{array}$ \\
\hline $\begin{array}{l}30^{\circ} \mathrm{C} .=73 \\
35^{\circ} \mathrm{C} .=74\end{array}$ & $\begin{array}{l}35^{\circ} \mathrm{C} .=68 \\
50^{\circ} \mathrm{C} .=68 \cdot 5\end{array}$ & $\begin{array}{l}35^{\circ} \mathrm{C} .=59 \\
50^{\circ} \mathrm{C}=66\end{array}$ & $\begin{array}{l}35^{\circ} \mathrm{C} .=6 \\
50^{\circ} \mathrm{C} .=6\end{array}$ \\
\hline
\end{tabular}

Tap water gave results practically identical with distilled water.

\section{(c) Factors depending on the Water, Mink, and other INGREDIENTS EMPLOYED}

It is the practice to add salt to margarine during the final stage of blending. In the use of the author's invention; ${ }^{15}$ of a machine for the continuous production of margarine, the salt is added in solution in the milk during emulsification. Drop number determinations have shown that $\mathrm{NaCl}$ promotes the dispersion of oils and fats in water. For example, at $35^{\circ} \mathrm{C}:-$

Coconut Oil in :

Butterfat in :

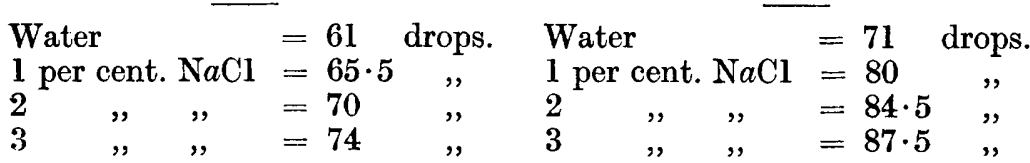

At 13 per cent. $\mathrm{NaCl}$ concentration (the concentration of the salt present in the aqueous phase of the total emulsion) no drop numbers were determined, because of sausage-like formations of the drops.

The explanation as to why $\mathrm{NaCl}$, which will "break" emulsions of oil in (say) soap solution, facilitates dispersion in pure water, seems to be that by preferential adsorption of the $\mathrm{Cl}$ ion at the oil-water interface, caustic soda is formed which unites with the free fatty acids present in the oil, and so forms a soap. Thus two coconut oils were examined at $35^{\circ} \mathrm{C}$. One had 0.07 per cent. free fatty acid, the other 1.85 per cent. In a 1 per cent. $\mathrm{NaCl}$ solution they gave drop numbers of 65.5 and 79 respectively. Actual tests on a works scale have shown that salt ( 2 per cent. concentration on the total margarine, 13 per cent. concentration in the aqueous phase) does facilitate emulsification. 
Emulsifying agents are frequently added to the milk or oil in margarine manufacture, and numerous patents for such additions exist, e.g., egg-yolk, lecithin, gelatin, glycerin, albumin, etc. Gelatin is an excellent emulsifier. A palm kernel oil giving a drop number of 73 in water in $30^{\circ} \mathrm{C}$. gave 120 drops in 1 per cent. gelatine. Two samples of oils at $25^{\circ} \mathrm{C}$. gave the following results :-

Cottonseed Oil in :

\begin{tabular}{|c|c|c|c|c|}
\hline \multirow{2}{*}{\multicolumn{5}{|c|}{$66 \mathrm{drono}$}} \\
\hline & & & $66 \mathrm{dr}$ & rops \\
\hline $0 \cdot 25$ per & cent & gelatine & 124 & \\
\hline 0.50 &, & ," & 137 & \\
\hline .0 & ", & $"$ & 143 & \\
\hline .0 & , & , & 149 & \\
\hline .0 & , & , & $149 \cdot 5$ & 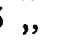 \\
\hline 0 & ," & , & $150 \cdot 0$ & \\
\hline
\end{tabular}

Arachis Oil in :

\begin{tabular}{|c|c|c|c|c|}
\hline Water & & - & -66 & Arops. \\
\hline 0.5 per & cent & gelatine & 140 & ," \\
\hline $1 \cdot 0$ & , & ", & 148 & " \\
\hline $2 \cdot 0$ & , & ," & 155 & , \\
\hline $3 \cdot 0$ & $"$ & ," & 163 & , \\
\hline
\end{tabular}

The curve given by plotting the results for cottonseed oil suggests a maximum effect at about 3 per cent., but this question demands further inquiry. ${ }^{16}$

It is now evident that extensive investigations require to be made before a thorough account of a margarine emulsion is complete. It is probably the most complex emulsion system in industrial practice. The oils and fats are not emulsified with water only (except in special cases, e.g., "pastry margarines") but with milk, and this milk has been artificially soured by the action of lactic acid bacterial. In the milk there is lactic acid, milk colloids, lactose and solid clots of casein. What the effects of these substances are on the emulsion is a field for further research.

Preliminary measurements indicate that lactic acid has a slight positive dispersing effect and lactose a more pronounced effect. Thus a coconut oil giving a drop number of 69 in water at $30^{\circ} \mathrm{C}$. gave a drop number of 116 in 1 per cent. lactose. In three separate solutions of lactose, coconut oil gave 116, 118 and 116 drops. Such a result is quite unexpected, and is receiving further investigation.

In conclusion, I take this opportunity of thanking Calder's Margarine Co., Ltd. (Liverpool), for affording me every facility to carry out these experiments.

\section{Bibliography}

1 Vide Clayton : "Theory of Emulsions and Margarine Churning," Margarine Journal, 2, 13, 503-4, 1920.

2 Hillyer, J. Amer. Chem. Soc., 25, 513, 1903.

3 Vide Blichfeldt, Eng. Pat. 4505, 1912.

4 Well-known types of continuous churns : Schröder, Eng. Pat. 25404, 1905 ; Germ. Pat. 309717, 1917; Risberg, Eng. Pat. 25890, 1907; Silkeborg, Eng. Pat. 4657, 1914 ; Blichfeldt, Eng. Pat. 18048, 1914; Leitch, U.S. Pat. 1266501, 1918.

5 Robertson, Koll. Zeits., 7, 7-10, 1910.

6 Briggs, J. Phys. Chem., 19, 478-99, 1915. 1919.

7 Clayton, Brit. Assoc. Colloid Reports, 2, 114, 1918; J.S.C.I., 38, 113-118T,

${ }^{8} \mathrm{~J}$. Ind. Eng. Chem., 12, 135, 1920.

- Journ. Chem. Soc., 1920, pp. 542-552.

$10 \mathrm{~J}$. Phys. Chem., 23, 634-9, 1919.

11 J.S.C.I., 35, 678, 1916.

12 J. Phys. Chem., 24, 120-6, 1920.

13 Vide Clayton, "Margarine." (Longmans), 1920, p. 36.

14 Collegium, 1910, 277-84, 285-87.

15 Clayton and Nodder, Eng. Pat. 147257, 1920.

${ }^{16}$ c.f. Holmes and Child, J. Amer. Chem. Soc., 42, 2053, 1920. 